\title{
From Scientific Communism to Political Science: The Development of the Profession in Selected Former Soviet European States
}

\author{
Tatsiana Chulitskaya, Irmina Matonyte, Dangis Gudelis, \\ and Serghei Sprincean
}

\section{INTRODUCTION}

In this chapter, we explore the trajectories of the evolution of political science in four former Soviet Socialist Republics after the collapse of the USSR in 1990-1991. We focus on two Baltic states: the Republic of Lithuania (hereinafter Lithuania) and the Republic of Estonia (hereinafter

T. Chulitskaya $(\bowtie)$

Faculty of Political Science and Diplomacy, Vytautas Magnus University, Kaunas, Lithuania

I. Matonyte

General Jonas Žemaitis Military Academy of Lithuania, Vilnius, Lithuania e-mail: irmina.matonyte@lka.lt

D. Gudelis

Faculty of Business and Public Governance, Institute of Public Administration, Mykolas Romeris University, Vilnius, Lithuania

e-mail: dgudel@mruni.eu

(C) The Author(s) 2022

G. Ilonszki, C. Roux (eds.), Opportunities and Challenges for New

and Peripheral Political Science Communities, https://doi.org/10.1007/978-3-030-79054-7_3 
Estonia) which were incorporated into the USSR in June 1940 and which by 2020 have become full-fledged members of the EU, NATO and the OECD; the Republic of Moldova (hereinafter Moldova) which in 1940 became a part of the USSR and re-established its independence in 1991, although a part of its territory (Transnistria) has been under the de facto control of the separatist government since 1990; and, finally, the Republic of Belarus (hereinafter Belarus), the legal successor to the Byelorussian Soviet Socialist Republic (Byelorussian SSR), which gained its independence in 1991 and since the mid-1990s has been involved in a process of integration with Russia. Since the spring of 2020, Belarus' society has been heroically trying to overthrow the existing dictatorship and to liberalize the country. These four case studies provide a good basis for testing several hypotheses relative to the developments of political science (hereinafter PS) in former Soviet republics and for a nuanced comparison of its institutionalization patterns. In the four country cases, we pay special attention to the context of democratization and to the effects of path dependencies.

The fall of the communist regime in Central and Eastern Europe, and the disintegration of the USSR, established significant premises for the development of democracy, of a free market and of civil society in the four countries concerned. Amidst the sweeping changes, Estonian, Lithuanian, Moldovan and Belarusian scholars from the social sciences and humanities, who had been previously involved, willingly or unwillingly, in teaching scientific communism and Communist Party (hereinafter CP) ideology and other related disciplines such as scientific atheism, political economy, dialectical materialism and so on were given the opportunity to explore new areas of research, particularly in the field of political science. The Perestroika period (1985-1990) and the subsequent political liberalization of four former Soviet republics created a unique opportunity for the emergence and institutionalization of PS as an academic discipline. On the one hand, there was a window of opportunity for PS to make a fresh start as a field of academic research with its own professional community. On the other hand, the newly emerging PS institutions and their staff had to cope with all kinds of challenges arising from the political, economic, social and cultural problems of the time and needs to deal with them on an individual level.

\section{S. Sprincean}

The Institute of Legal, Political and Sociological Research, Chisinau, Republic of Moldova 
To promote and facilitate these transformations, numerous initiatives have been launched by external actors (the European Union's educational programmes such as TEMPUS, Open Society organizations, the programmes sponsored by the US and European governments, targeted projects of the Western universities and various European foundations, and so on). Despite the impetus and assistance provided by external stakeholders, towards the convergence of the newly launched PS institutions towards the Western standards in the early 1990s, the development of PS in Estonia, Lithuania, Moldova and Belarus differed perceptibly from one country to the other in its scope and intensity, its teaching and topics of research, its level of internationalization and its orientation in terms of international cooperation.

The similar nature of PS institutionalization in the post-Soviet countries could be accounted for by their common points of departure. In the USSR Russian was the "language of international communication" and many academics, who were later to become Estonian, Lithuanian, Moldovan, or Belarusian political scientists, graduated or completed postgraduate studies in fields such as scientific communism, philosophy, history and law, many of them doing so at the leading universities in the Soviet Union, such as Moscow State University, Leningrad State University, Shevchenko State University (Kiev), Rostov State University and the Belarusian State University (Minsk). Studying at those universities gave such students prestige, recognition and professional networking opportunities, and substantially contributed towards enhancing their future careers. Even though the sub-cultures and institutional design of their workplaces in Soviet Tallinn, Vilnius, Chisinau or Minsk were characterized by certain idiosyncrasies, these Soviet scholars shared many common features deriving from their education, reinforced through Soviet propaganda and surveillance, and put into practice through centrally planned research programmes and professional events.

In 1990, the four Soviet republics had to break away from the highly centralized authoritarian state. During the process of post-Soviet transformation, the former Soviet republics have increasingly diverged mainly due to the specific nature of their respective political and social dynamics. Lithuania and Estonia have pursued pro-European policies and displayed a strong desire to join the EU and NATO culminating in their full membership of both in 2004. Moldova and Belarus, on the other hand, have followed different political trajectories for internal and external reasons, the most important of which being: strong Russian geopolitical pressures; 
the weakness of their respective civil societies; and the considerable degree of Sovietisation inherited from the USSR. According to Levitsky and Way (2010, p. 537), "consolidated democracies" were thus established in the Baltic States, while the political and social evolution of Moldova led to the establishment of a "defective democracy", and developments in Belarus resulted in a "competitive autocracy".

As pointed out in Chap. 2, the evolution of democratization can be considered an important factor shaping the institutionalization of PS. The present chapter focuses on Soviet legacies and path dependencies as factors influencing the institutionalization of PS in the four countries concerned here. As long as political science is appreciated as the science of democracy (Eisfeld et al., 2019, p. 199), its identity and autonomy are particularly important. ${ }^{1}$ In other words, PS as an academic discipline must not depend on the whims of the State, and its professional community has to be able to define and follow its own internal rules, norms and ethical principles.

The analysis of the institutionalization of PS in post-Soviet countries reveals the increasing social impact of political science and its institutions on democracy. Alongside the intellectual developments seen in academia, the democratizing countries' respective governments have embraced a normative pro-democratic approach to domestic and foreign policies. A pluralistic national environment promotes academic freedom. PS can manifest itself in non-democratic surroundings, but it will take very specific forms and perform narrow functions serving the ruling elites when doing so. The institutionalization of PS as a discipline, in this context, is an important indicator of a country's democratization and of its sustainable future development.

In this chapter, we analyse the process of PS institutionalization in the period before the 1990s and after the collapse of the USSR. We examine the formation of post-Soviet PS in Estonia, Lithuania, Moldova and Belarus, and in doing so we offer references to the relevant Soviet experiences and practices and explore the different, but also in some respects similar, trajectories of the discipline's development in these countries. We

\footnotetext{
${ }^{1}$ According to the operational definition of institutionalization introduced in this volume, political science is institutionalized when it meets five specific requirements, namely: it is a relatively stable discipline; it has an identity of its own; it has a fair amount of autonomy when it comes to establishing its internal rules and norms; it can reproduce (and is also able and willing to internationalize); and it is accepted as a legitimate discipline. Of these five components of institutionalization, there shall be no detailed examination of political science's reproduction and legitimation in the present chapter.
} 
specifically focus on Belarus as an extreme case of the development of political science in a non-democratic environment. In particular, we investigate the similarities and differences in the current state of the discipline in those four countries, by analysing the formation of its identity and the establishment of its autonomy. In the concluding section, we briefly reflect on the current challenges faced by PS in these four countries.

We base our analysis on an institutional approach, and we actively use the descriptive method while exploring the Soviet period and the four country-cases. For each case, we analyse comparable indicators and examine the most prominent features. We realize that when analysing PS developments in post-Soviet countries, one has to deal with several constraints including the lack of information on the local predecessors (institutions and prominent figures) of PS during the Soviet period in Estonia, Lithuania, Moldova and Belarus, and the limitations on open sources when it comes to post-Soviet Belarus.

\section{The Soviet Period: The Ideological and Intellectual Trajectories of Political Science}

The very concept of "politics" in Soviet times had a dual meaning and performed a dual social function. On the one hand, politics was not a topic that could be freely discussed, whereas on the other hand, it was present in all spheres of public life, including higher education, and it provided guidelines for all public activities. Highly specific institutional and intellectual approaches to PS were grounded in this dualism of "politics" within the former Soviet Union.

From a chronological perspective, Smorgunov (2015, p. 125) distinguishes between two periods in the development of PS in the USSR. The first, from the 1920s to the 1950s, was a period of cryptopolitology during which political research was undertaken under the name of other disciplines recognized by the Soviet regime, such as history, jurisprudence and Marxist philosophy. The second period, from the mid-1950s to the mid1980s, was a period in which "political research became an occupation not secret but also not yet fully recognized" (Il'yn, 2001; Vorob'ev, 2004). ${ }^{2}$

\footnotetext{
${ }^{2}$ It should be mentioned that during the first (pre-WWII) period there were also original developments, paving the field of political science research and teaching in Estonia, Lithuania, Moldova and Belarus caused by important political events (proclamation of national independence, in particular).
} 
The importance of an ideologically "proper" education had already been established in the USSR during the early years of Soviet power. In fact, as early as the 1920s/1930s, the syllabuses and curriculums of the humanities and social sciences emphasized the ideological underpinnings of socialist society (Shevchuk, 2014). In 1925, "An introduction to Marxism-Leninism" became a mandatory course present in all higher education programmes in the USSR. In 1938, a guidebook entitled "A brief course in the history of the Communist Party of the Soviet Union (CPSU)" was published. The book was a major work of reference in all disciplines for almost twenty years, up until the XXth Congress of the CP of the USSR in 1956 (when the process of destalinization started). In 1939, a special All-Union Order on Higher Education Affairs (in Russian, Vsesojuznii komitet po delam vyschei shkoly) introduced obligatory courses in the History of the CPSU, Political Economy and Philosophy. The main idea behind the new courses was the unification (and the overcoming of any decentralization) of CP propaganda and education among the Soviet republics, designed to avoid any heterogeneity of such (Saprykina, 2016).

After WWII, the propagandistic, highly ideological unit in the social sciences and humanities continued to be developed in the USSR. In 1956, Soviet universities began teaching the History of the CPSU instead of Marxism-Leninism, while new subdivisions within the universities' departments of Marxism-Leninism were established. In the late 1950s, subdivisions of the history of the CPSU, of political economy and of philosophy were created in many universities (Opiok, 2019).

In 1962, Mikhail Suslov, a leading CP theoretician and member of the USSR Politburo, officially proclaimed that the political theory of communism would henceforth be called "scientific communism" (nauchnyi kommunizm), thus in effect establishing a new discipline (Theen, 1971) as an additional and mandatory part of all higher education (hereinafter HE) programmes in the USSR. The old "Bible" of the Communist party's history-the handbook A Brief Course of CPSU history-was criticized and abandoned. In 1960, a new handbook entitled CPSU history by Boris Ponomarev was published, and this was to become the main reference work in Soviet HE courses (Saprykina, 2016).

The establishment of scientific communism as a separate academic discipline was accompanied by the reviewing of the entire social science-humanitarian sector of HE. In 1974-1975, an obligatory state exam in scientific communism was introduced as a requirement for the completion of a student's higher education (Nemcev, 2016). Thus, greater 
space was given over to scientific communism and other ideologically related subjects during the late Soviet period, and this was true for the entire period of study in any HE institution in the USSR.

When Gorbachev came to power in 1985 and the period of Perestroika started, departments of scientific communism, together with other social science-humanitarian departments in Soviet universities, were faced with a number of significant challenges. Changes in the CP's general line required those at universities to engage in a certain "revisionism" of established Soviet dogmas. However, a lot of HE staff members were significantly involved in divulging communist propaganda. In 1989, the Head of the USSR State Committee of People's Education, Yagodin, issued an Order "On the Rebuilding (perestroika) of Social Sciences Teaching in the HEIs of the Country": this order required universities all over the country to introduce new courses in Social-Political History of the 20th Century, Philosophy, Political Economy and the Problems of the Theory of Contemporary Socialism (Opiok \& Sugako, 2010). In the late 1980s to early 1990s, the first courses in political science as such were introduced in all Soviet republics.

Together with a highly ideological system of HE in the Soviet Union, there were also educational programmes specially designed for the CP elite. Fifteen 'higher party schools' were established at central and regional levels in 1946. Initially, attendance of such schools lasted for two years, but this was subsequently extended to three years (covering the period 1954-1956) and then to four years (1956-1990) (Gvozdeva, 2010). The CP schools taught and trained senior party professionals who were to work and/or worked in the party apparatus, in factories or in power structures (party committee instructors, secretaries of Komsomol i.e., communist youth organizations, trade union chairpersons and so on). The curriculum of these schools included economics, management studies and statistics, as well as subjects related to the political sciences, such as social process management, Marxist philosophy, scientific atheism, political economy, scientific communism, the history of the communist labour movement, the history of the USSR, international relations, foreign policy, political-economic geography and the construction of the CP (Samoškaitè, 2013).

During the entire Soviet period, there were CP schools operating in Vilnius (Lithuanian SSR), Chisinau (Moldavian SSR) and Minsk (Belarusian SSR). However, in 1956, a decision was made by the Central Committee of the CPSU, with the proclaimed aim of network 
optimization and the improvement of the quality of education, which stopped students from being admitted to higher party schools in certain cities, including Tallinn (Estonian SSR).

Specialized CP research centres also existed. Institutes of party history which were brunches of the founded in 1948 Institute of MarxismLeninism (IML) under the Central Committee of the CP of the Soviet Union played an important role in the Soviet social science research system. The employees of these institutes translated into their respective national languages, and commented on and published, the documents of the CP of the USSR, as well as conducting research into the local and national history of the communist party. Those institutes tasked with researching into and documenting the party's history also supervised the $\mathrm{CP}$ archives in the Soviet republics.

In terms of content, PS in the post-Soviet countries developed on the basis of various intellectual and organizational traditions existing during Soviet times (Smorgunov, 2015, p. 125). The first and overarching such tradition was Marxist-Leninist socio-political theory, which served as a basis for the activities of "scientific communists". The second was the allpervasive criticism of the bourgeois ideology underlying Western political science and liberal-democratic politics. The third was related to regional studies (of different polities and regions of the world). The fourth encompassed the analysis of constitutional orders, institutional designs and descriptive sociological and ethnographic data. The fifth originated from synergies with Soviet sociologists.

The first intellectual tradition, focusing on scientific communism, consisted in the investigation of class struggle, socialist revolution, the development of socialism and the construction of communism. Soviet authorities used "scientific communism" as a synonym of Marx and Engels" "scientific socialism", although the former placed the emphasis on Lenin's theory and on the doctrines of the CP of the Soviet Union. The publications of the specialists in scientific communism purportedly addressed the problems of power, social relations (social engineering), political culture, the history of Marxist theory and revolution. However, in reality, scientific communism justified the rule of the $\mathrm{CP}$, state violence and other repressive practices and the existence of certain institutions (including the KGB, labor camps, etc.) in the USSR.

The second tradition concerned the Soviet propaganda heavily criticizing the bourgeois world and capitalist worldviews. Many researchers were involved in criticizing Western ideologies, in attacking the alleged 
bourgeois counterfeiters of history, and social institutions (Smorgunov, 2015). While access to foreign authors and academic publications was generally not easy to obtain, Soviet social researchers nevertheless reflected on such writings (insofar as they were accessible). An important element of reflection in this case was to "present their texts as critiques from a Marxist-Leninist perspective" or to discuss Western ideas "in the sense of their contradiction to Marxist-Leninist philosophy and incompatibility with the position of dialectical materialism as the only true philosophical doctrine" (Dudchik, 2017, p. 106). In the final years of the USSR's existence, criticism of foreign authors was toned down somewhat, and Soviet writers even demonstrated a certain acceptance of Western theories.

These two disciplinary currents, that is, the active promotion of scientific communism and the criticism of Western ideas, under variable structural designs (in departments of history, scientific communism, political economy, the history of philosophy, atheism, the history of the Soviet Union communist party, etc.) were present in practically all HE institutions within the USSR and constituted the guiding principles of all teaching and research.

The third PS intellectual tradition emerged in those Soviet academic institutions that studied different countries and regions of the world. It was less ideologically grounded and more oriented towards empirical research, than the aforementioned traditions. Several specialized research institutions, most of which were established in or after 1956, gave rise to this tradition (Galkin, 2010). Furthermore, there were a series of "sectoral" institutes (for example, the Institute of the International Labour Movement (IMRD)). These institutes proliferated during the Khrushchev years, and in Brezhnev's period, they conducted studies that were of importance to policymaking. They employed numerous researchers conducting specialized studies resulting in classified information. Selected experts from these institutes were also members of various ad hoc committees set up by the Ministry of Foreign Affairs and the KGB in order to study particular problems or monitor important events (Kitrinos, 1984). All these institutes were based in Moscow, and as a rule, their leading scholars were graduates from Moscow or Leningrad universities, almost all of whom were Russian nationals.

The fourth intellectual tradition was promoted by legal scholars, who analysed the constitutions of different countries from an institutional perspective. In 1960, the Soviet Association of Political (Public Administration) Sciences (in Russian, Sovetskaja associacija politicheskih 
(gosudarstvovedchenskih) nauk, SAPS) was established, and from then on Soviet academics were involved in the IPSA's activities, albeit to a limited extent (Irkhin, 2016, p. 203). As was the rule in the Soviet system's hierarchical organization of society, the members of the Association who had Western contacts were mainly academics from Moscow and Leningrad. Not surprisingly, when the IPSA held its 1979 Congress in Moscow, the Soviet Union's participants, numbering $260^{3}$ (Irkhin, 2016, p. 205), were all from the Russian SFSR, with none from the other Soviet republics. At the same time, however, in 1980, divisions of the SAPS were established in several Soviet republics, namely the Latvian SSR, the Kazakh SSR, the Uzbek SSR, the Kyrgyz SSR, the Tajik SSR and the Turkmen SSR. Attempts were also made to bring together individual members of the association in the Soviet republics of Transcaucasia and Estonia (Smorgunov, 2015).

The fifth intellectual tradition which fed the community of political science researchers in the USSR is associated with sociological research and the activities of the Soviet Sociological Association (Smorgunov, 2015). Greenfeld (1988) observes that Soviet sociology was always very close to political science and public administration research. Although Soviet sociologists adopted some of the methods of Western sociology, sociology itself was an administrative tool of the Soviet government rather than a science per se (Greenfeld, 1988). In the early Soviet period, there were restrictions on sociological research, although these were relaxed to a certain extent in 1956. The Soviet Sociological Association was established in 1957, and sociology itself was recognized as a fully fledged branch of the social sciences. Political sociologists carried out empirical studies in the domains of public opinion, social behaviour and political culture. Specialized sociological research institutes were established in all four of the Soviet republics examined here.

Summing up, PS did not exist as a separate academic discipline in the USSR before 1990. Political education was fragmented, and research was conducted under a series of different disciplinary labels (scientific communism, philosophy, history, regional studies, law and sociology). The most important function of all these disciplines was to provide Soviet citizens with an education based on sound ideological grounds. However, certain institutional developments (the Soviet Association of Political Science, the historical archives and inventories, the specialized laboratories and divisions of social research, etc.), together with the educational and

\footnotetext{
${ }^{3} 18 \%$ of all participants at the IPSA's 1979 Congress.
} 
research methods adopted by Soviet scholars specializing in various aspects of the social sciences, formed the basis for the development of post-Soviet political science. The collapse of the USSR and the dissolution of the centralized system of $\mathrm{HE}$ and research served as a starting point for the development of political science in the newly established, sovereign, post-Soviet nations of Estonia, Lithuania, Moldova and Belarus.

\section{The Organizational Units of PS as an ACADEMic Discipline}

This section provides an overview of the development of PS as an academic discipline during the breakthrough years (1985-1991) and traces that development up to the end of the 2000s. This period started with a series of radical socio-political changes brought on by Gorbachev's glasnost' and perestroika, the "national awakening" movements, and the restoration of independence in Estonia, Lithuania, Moldova and Belarus. In Estonia and Lithuania, widely supported social movements led to the country regaining its independence in the spring of 1990. The eventual dissolution of the Soviet Union marked the birth of several new independent states, including Moldova and Belarus.

The following years brought a series of no less challenging, albeit less spectacular, changes to political and civic life, including that of academia. In the beginning, a lack of experienced political scientists and specialized political science units represented the major problem. When scientific communism as an academic discipline vanished from the universities, and PS was able to emerge out into the open, its initial manifestations appeared within "old" disciplines such as law, philosophy, history and sociology.

In Estonia, political science's formative period was closely interconnected with intellectual influences from the West, and the University of Tartu represented a major platform for political science's development. The University of Tartu became a hub of comparative political studies and international relations. In 1992, the University established a new School of Social Sciences, and the first chair was held by Rein Taagepera who had taught at the University of California-Irvine. ${ }^{4}$ The next step was the creation of an interdisciplinary three-year BA programme for sociologists, public administration scholars and political scientists. It took several more

\footnotetext{
${ }^{4}$ Taagepera was appointed Joint Professor of Political Science (üldpolitoloogia in Estonian) at the University of California-Irvine and the University of Tartu.
} 
years (until 1995) to establish the Department of Political Science, to appoint the first professor of political science (Kaido Jaanson, a historian and political scientist specialized in Estonian-Scandinavian relations in the early twentieth century) and to create a self-standing BA curriculum at the university. Another direction taken by PS was that developed at Tallinn University (known at the time as the Tallinn Pedagogical Institute), where political studies and research focused on the field of public administration.

In Lithuania, PS as an academic discipline was promoted by historians, lawyers, philosophers and sociologists who became political scientists. This diverse group of intellectual entrepreneurs launched new study programmes, periodicals and regular conferences, as well as translated and published numerous books and articles dealing with politics. The very term "scientific communism" became pejorative. The community of political scientists came together around the Institute of International Relations and Political Science at Vilnius University, which was established in 1992 (Jakniūnaitè \& Vinogradnaité, 2010, p. 178). The lectures on different subjects within the field of political science were taught in other departments of the humanities and social sciences faculties. For example, in Klaipeda University political science was taught in the Department of History and Sociology of the Faculty of Human and Natural Sciences up until 1993. Upon the initiative of the Lithuanian diaspora from the USA, Vytautas Magnus University (VDU) was re-established in 1989 in Kaunas. ${ }^{5}$ VDU cherished the spirit of the "liberal arts", unheard of in Lithuania up until then. Its bachelor PS degree programme was launched by established American and Canadian scholars of Lithuanian origin together with young Western researchers (from the USA and Norway in particular).

In Moldova, PS was developing on the institutional and intellectual grounds of scientific communism, and knowledge and human resources were imported from neighbouring Romania. In 1989, the University of Moldova's Department of Scientific Communism was renamed the Department of Political Science and Socialist Theory, while the Department of the History of the Communist Party of the USSR became the Department of Political History. As in other post-Soviet republics, also in Moldova, there was a lack of teaching staff initially, and consequently, former professors of scientific communism, law and other social sciences

\footnotetext{
${ }^{5}$ The Soviet authorities had closed it in the 1950s and divided it into specialized institutes of technical science, agriculture and medicine.
} 
started teaching PS. Given the lack of personnel, the PS faculties began to recruit new staff, most of whom were graduates from universities in Romania (Gorincioi, 2010). In Moldova, fiercely disputed issues of political and cultural identity impacted the situation in terms of the language of instruction at the universities. After the establishment of PS as a discipline, the courses (as in other academic disciplines) were taught in one of two languages: Romanian (2/3) and Russian (1/3). In the late 1990s, the first ever PS textbook in Moldova was published in both of the aforesaid languages (Moshneaga \& Saca, 2004).

PS in Moldova exists within the troubled political situation the country finds itself in, with an ongoing, unresolved conflict in Transnistria. De facto governed by pro-Russian separatists, this territory has its own University (Pridnestrovian State University-PSU) which as a result of the Transnistria war is based in the premises of the former Taras Shevchenko State University of Tiraspol, removed to Chisinau in 1992, which has its own Institute of Public Administration, Law and Social Sciences. However, as is the case with all social infrastructure within the region (de Waal \& von Twickel, 2020), PSU has been beset by problems regarding the quality of education, due to very limited funding and outdated materials.

PS emerged in Belarus within the context of the deconstruction of Soviet social sciences (history, philosophy and sociology) and scientific communism (Antanovich \& Liahovich-Petrakova, 2009), and under external influences from both the West and Russia. The first institute of PS in the country was created at the Minsk Higher Communist Party School, which after 1990 was renamed the Institute of Political Science and Social Governance of the Communist Party of Belarus (CPB). However, the Institute had a short life and was closed in 1991 after the activities of the CPB had been banned by the Supreme Council of BSSR. At the Belarusian State University (BSU), PS only replaced the existing ideologically biased Soviet disciplines in formal terms, whereas the majority of teaching staff and some course content remained the same as before.

In 1991, after the establishment of the first PS department at the BSU (initially within the Philosophy-Economics Faculty before being subsequently transferred to the Law Faculty), the design and content of the first PS degree programme were taken from the Moscow State University (MSU) curriculum (Naumova, 2010). At the same time, western influence and programmes for the promotion of democracy impacted the formation of PS in Belarus. 
In the early 2000s, PS departments (either specifically designed for the teaching of political science or together with other social sciences) were created in all of Belarus' state universities. During that period, PS also appeared in the curricula of the country's private universities. While as a rule Belarus' private universities simply reproduced/copied the curriculum of the BSU, there was one important exception to this rule: in 1993, the Franco-Belarusian Faculty of Political and Administrative Science was set up at the private European Humanities University (hereinafter the EHU). The EHU was funded by diverse international donors, and the Franco-Belarusian Faculty itself received financial support from the French Embassy in Belarus. The EHU had a reputation of being an island of academic excellence, promoting liberal democracy and being supported by various Western organizations (Naumova, 2010). With the exception of the EHU, the quality of PS programmes at Belarusian private universities was perceived, in the public's eyes, to be lower than that of the country's public universities. However, this scepticism was not so much the result of any underperformance, but rather the consequence of the general negative attitude towards the private sector in a country where the public sector dominated all spheres of public life.

Further development of PS in Belarus mainly depended on the increasingly non-democratic tendencies and authoritarian leadership of Alyaksandr Lukashenka. The national PS community's reaction was twofold. On the one hand, academic PS continued to develop in state-run universities, where the ideological and political components of loyalty to the regime were cultivated. On the other hand, a number of independent centres of political analysis and think tanks were created (usually with the support of Western donors). The split between these two communities deepened over time. The official form of PS exists within the heavily centralized national policy in the sphere of higher education. Think tanks have a somewhat broader scope; however, their existence depends on Western donors. The efforts made to promote and consolidate a common platform for Belarusian think tanks, by the Belarus Research Council (BRC) established in 2012, with substantial financial support from foreign donors (in particular, from USAID), ceased after 2016. However, owing to diverse internal and external developments, the gap between the two PS communities in Belarus has been bridged to a certain extent since 2014, and a new type of "hybrid" think tank has emerged with support from both government authorities and Western donors (Chulitskaya, 2021). 
The political elites in Belarus have significantly interfered in higher education. One of the clearest cases of such interference was the closure of the EHU in 2004. ${ }^{6}$ Initially, Belarus' non-democratic authorities considered PS to be too general, and even unnecessary. However, with the strengthening of the nondemocratic regime, the authorities changed their attitude and followed the Soviet example by starting to promote PS as a tool of non-democratic education and indoctrination. In the mid-1990s, the Belarusian Ministry of Education included PS as an obligatory core curriculum course in all undergraduate programmes offered by the country's state-run universities. In keeping with Soviet tradition, in 2003 Lukashenka demanded that a system of ideological education be put in place. Consequently, state-run universities developed and introduced a special course in state ideology. As a result of these changes, the PS departments had to reformulate the entire design of their PS curricula, and this process was not completed until 2008. With all the bureaucratic changes in the teaching of PS and the lack of professional prospects for PS graduates in an authoritarian political system, the BSU and other state-run universities offer PS BA programmes providing graduates with a dual degree in political science and law. The second of the two subjects is more appealing to students, who see it as more "useful" in terms of career prospects.

Among the four post-soviet countries examined in this chapter, PS only started anew in Estonia. It is worth noting that, as previously mentioned, the CP's higher school of studies in Tallinn ceased functioning in 1956. During Soviet times, the Estonian community of scientific communists was fragmented and weak. Therefore, as Pettai (2010) states, political scientists took advantage of this "backwardness" to create a new discipline practically from scratch, and this new discipline had the chance to become quickly internationalized and open to new developments.

In Lithuania, Moldova and Belarus, PS first appeared in the official education system within the framework of "traditional" disciplines such as philosophy, history, law and sociology. In Moldova and Belarus, scientific communist organizational units played an essential role in the formation of PS. In Lithuania, Western influences were quick to manifest themselves, in terms not only of the liberal political science education offered by universities but also of new institutional ventures undertaken. In Moldova,

\footnotetext{
${ }^{6}$ Later on, the EHU was reopened "in exile" in Lithuania, but in its de facto guise it became a different institution, without PS being a leading discipline despite its declared mission including "civic education".
} 
PS was established on the basis of the country's existing university departments, and of personal professional networks and Moldova's cultural affinity with neighbouring Romania. However, political turmoil in the country affected the sphere of HE, with the introduction of two languages for teaching purposes (Romanian and Russian), and the corresponding different socio-cultural traditions, and the existence of a separate system of education in the disputed region of Transnistria.

In Belarus, as in Moldova, the institutional foundations of PS were represented by Soviet social sciences and scientific communism. Unlike in Estonia and Lithuania, an emergent PS in Belarus and Moldova experienced not only Western but also Russian, influence (pressure). While in the early 1990s, the development of PS in Belarus followed similar patterns to those observed in Moldova, subsequently the deterioration in the political situation in Belarus led to a return to previous Soviet legacies. Official PS at the country's state-run university became an obligatory (but practically meaningless, in the students' eyes) subject, while an additional course in state ideology (a version of scientific communism) was developed. Some of the oppositional-minded political scientists left their university posts to work for think tanks which at least provided them with opportunities to carry out applied research. Alternative opportunities to get a PS education at a private university were ended when the only such university (the EHU), sustained by Western sponsors, was closed in 2004.

The formative period of PS varied across the four countries as a result not only of their differing national politics, economy and social sphere but also of their respective foreign policies and international relations. While Estonia and Lithuania's pro-European foreign policy promoted Western values in relation to institutional developments in all areas of public life (including academia), the vectors of Moldova's foreign policy vacillated, while Belarus attempted a balancing act between East and West (albeit gravitating more towards Russia). Consequently, Estonia and Lithuania followed a characteristically western-type type promoted internationally by the IPSA, that recognized "PS as a science of democracy". In Moldova, PS received a certain pro-Western input with additional opportunities for education, science and research being made available following the signing of the Association Agreement with the EU in 2014. However, geopolitical shifts and the unresolved conflict in Transnistria have perceptibly destabilized PS in Moldova. Different geopolitical paths have had an effect on international scientific cooperation and the internationalization of PS education. While Estonia and Lithuania are actively involved in diverse 
socially and academically important international scientific projects (with academic institutions and social partners from the EU, the USA and other countries), Moldova and Belarus fluctuate in terms of their chosen partner-sometimes this is Russia and at other times it is the EU-and underperform in terms of their research output (Mazepus et al., 2017).

\section{Political Science: An Independent Profession Or Not?}

As postulated in Chap. 2 in regard to the profession's identity, the basic expectation is to establish diverse organizational entities, including academic units and political science associations, that are based on the norms of the profession and are proof of political scientists' professional identity. In the previous section, we briefly discussed the very first organizational structures created to host the nascent political science in the four postSoviet European countries examined here. The inventory of initial structures, and the accounts of their further development, clearly show that national and international political factors have a substantial impact on the identity of political scientists comprising a specific professional body.

In post-Soviet Estonia, Lithuania and Moldova, PS became a clearly identifiable, visible academic discipline distinguishable from other neighbouring disciplines. In this respect, the development of PS in Estonia was the swiftest. The Lithuanian experience proved more variegated, as it included a wider range of stakeholders from previous Soviet times (including higher education institutions), as well as a plethora of Western sponsors. In Moldova, while the organizational units marking PS as a separate academic discipline emerged smoothly, the identity of the PS community quickly proved to be rather unsubstantial. In Belarus, the short-lived crystallization of PS was interrupted by the fusion of political science and law; this organizational amalgam was a further precursory sign of the ideologization and political instrumentalization of PS as a discipline within the country, marking a shift towards authoritarian rule. The "oppositional/ alternative" think tanks, although to some extent contributing towards building and maintaining PS' professional identity, at the same time had to fight to survive.

However, as Chap. 2 points out, a clear identity is needed for the benefit of the self-esteem of political scientists themselves. Thus, the selfidentification of the academic community and the development of the 
profession's "mission and vision", have together enhanced the institutionalization of the profession. The process and requirement of identity formation do not exclude cooperation with other disciplines. On the contrary, multi-disciplinary approaches and openness in academic terms, are not detrimental to the identity of contemporary PS. In this section, we ask the following questions. What are the boundaries of PS as a discipline, and what are its lines of separation from, and patterns of cooperation with, other social sciences and the humanities? How are PS doctoral programmes organized? How do political science associations operate, if at all? Is PS visible in the media and at public events? What prestige and career prospects do PS graduates enjoy?

While the identity of PS substantially depends on the public's perception of the discipline, mostly based on the presence of political scientists in the media and at public events, in Estonia and Lithuania the future development of political science will be one of its growing complexity. In neoliberal Estonia, a premium is placed on political (and social) science as a whole being more clearly performance-orientated (quantifiable in terms of the number of publications, the project budgets awarded, the partnerships with other actors established, etc.). Typically, strategic priorities encourage PS subfields to break off from PS and establish new organizational units. On the other hand, in terms of student recruitment, the universities are under pressure to consolidate with adjacent fields, which means that PS could get incorporated into the general category of the "social sciences". The creation of the School of Governance, Law and Society at Tallinn University in 2015 is a sign of such a trend. When it comes to the visibility of political scientists within the country, their focus on academic excellence rather than public promotion means that their public presence is of a rather limited character.

In Lithuania, political scientists are very visible in the public sphere, commenting on public affairs in the mass media and participating in various forums. Even a very popular comedy show "Dviračio žinios" has two distinctive characters (mice politologists) who comment on domestic politics and international affairs. The neoliberal reform of student enrolment together with efforts to consolidate the national HE system are shaping the PS community in Lithuania. The Institute of International Relations at Vilnius University (TSPMI) leads the field in terms of student

\footnotetext{
${ }^{7}$ Which started as a radio show in the early 1990s, later became a commercial TV program, and since 2020 it has been produced by the country's public TV broadcaster.
} 
enrolment and public visibility. It is followed by Vytautas Magnus University (VDU), located in the town of Kaunas, which is less appealing to students and scholars than the capital city. The Military Academy of Lithuania is expanding, especially in terms of the number of students (cadets) admitted to the Academy. Other universities (Klaipeda, MRUNI, KTU and EHU) are shrinking in terms of PS student numbers and of the quality of their PS programmes. Lithuanian universities run several interdisciplinary programmes (at BA or MA level), where PS is combined with communication studies, public administration, management or economics.

In Moldova, political scientists complain of political "decision-makers" lack of interest in non-speculative, scientifically argued opinions. Political scientists are scarcely visible in the public sphere, with the exception of those political experts who are able and willing to act as political advisors and designers of PR campaigns. In fact, in Moldova in 2020, the universities, including their departments of PS, are bereft of students. At the same time, the research units (institutes, centres, sections and sectors) have seen a decline in the number and the financing of research projects (funding has dropped from $0.5 \%$ to $0.18 \%$ of GDP in the last five years). Practically deprived of students and public funding, PS departments are struggling to survive.

In non-democratic Belarus, political scientists from the state-run universities, unlike their Soviet predecessors working at CP schools, are hardly ever-present in the media or at public events. On rare occasions, the authorities get academics to appear on propagandistic TV shows or write newspapers articles, in order to demonstrate their approval of questionable decisions on domestic or foreign issues. Representatives of oppositional/alternative think tanks are quite active in the oppositional media. However, both the media themselves and the aforesaid experts are in most cases marginalized by the authorities. Political science, public administration and international relations exist as separate academic disciplines, and they are concentrated in different faculties or even universities. ${ }^{8}$ From an institutional point of view, these disciplines (branches) are separated from each other, and their representatives (with the exception of a restricted group of "pure" political scientists) do not see themselves as "political scientists", or their activities as "political research" (Chulitskaya, 2021).

\footnotetext{
${ }^{8}$ For instance, the main HE institution specialized in public administration is the Academy of Public Administration under the Aegis of the President of the Republic of Belarus.
} 
The remaining separate PS organizational units (PS departments) are closely interconnected with law or (in some cases) with economics, as mentioned above, and this causes tension between the representatives of both disciplines. The representatives of law as an academic discipline do not recognize political science's standing as "a science"; furthermore, the two disciplines battle for the dwindling number of students seen in the country in recent years.

When it comes to the topics of $\mathrm{PhD}$ dissertations in Estonia, at both Tallinn University and the University of Tartu there has been a mix of international relations (regional geopolitics), comparative politics (party research as well as ethnic relations) and public administration (policy studies). These domains have remained relatively constant, whereas political theory has been less well represented. Furthermore, PS departments in Estonia tend to demand high standards from their teaching staff and researchers. Thus, they tend to recruit researchers (initially of Estonian origin, later of diverse origins) who have been awarded their PhDs abroad (primarily in the USA, but also in Germany, France and Finland).

In Lithuania, all doctoral dissertations in the field of PS are grouped together into one category, that of the Doctor of Social Sciences. PhD topics sometimes relate to other social science fields, such as economics, sociology, management and administration, philosophy or law. The topics covered by $\mathrm{PhD}$ dissertations have significantly expanded and evolved over the three decades. The first PhDs in PS in Lithuania were awarded in 1993 (concerning theories of international political integration) and in 1996 (concerning the development of the party system in Lithuania). There are certain differences between the topics covered by dissertations submitted to the two separate PhD Committees of Vilnius University and Vytautas Magnus University (jointly with Kaunas University of Technology, Klaipeda University and the Military Academy of Lithuania). Dissertations submitted by PhD students at Vilnius University tend to focus on international relations, foreign policy and EU studies. While the VDU doctoral school focuses more on public policy, political campaigns, public administration and security studies. In 2000-2009 (pre- and post-EU accession) the topic of the EU dominated PhD dissertations, while since 2010 dissertations have started focusing on broader issues of international relations, area studies and defence policy, in particular in relation to Russia.

In Moldova, the topics covered by $\mathrm{PhD}$ dissertations tend to be rather diversified, although according to national records, from 2005 till 2020 the majority of dissertations have belonged to the thematic group entitled 
"Theory, methodology and history of political science; political institutions and processes". The second, smaller group of dissertations, have addressed the "Theory and history of international relations and global development". Content-wise, over the last decade topics such as migration, European integration and national security have also been dealt with, whereas during the previous decade, geopolitics, international relations and political institutions in the process of democratization were analysed (NCAA of Moldova 2020).

In Belarus, PS doctoral studies (aspirantura) (since Soviet times an unchanged university qualification) exist as a standalone programme supervised by the Higher Attestation Commission (HAC). The PS aspirantura programmes are run under three thematic labels: "Political Institutions, processes and technologies"; "Theory and Philosophy of Politics, History and Methodology of Political Science" and "Political Problems of International Relations, Global and Regional Development".

When it comes to building and fostering the identity of political science, national PS associations represent a suitable indicator of the strength of the PS community in a given country. Estonian political scientists formed a short-lived Association of Political Science in the early 1990s. However, members of a small and internationally highly mobile community of Estonian political scientists soon ceased to believe in the need to engage in collective action or collective interest representation. Rather, Estonian political scientists prioritize institutional, not individual, membership of international PS entities (e.g. institutional membership of the European Consortium for Political Research, of the European University Institute, etc.).

In 1991, scholars from Vilnius and Kaunas established the Lithuanian Political Science Association (LPA). The LPA was one of the first from Central Eastern Europe to join the IPSA in 1994. The LPA is a selfgoverning organization representing the interests and ethics of political scientists in Lithuania. The LPA currently has around 70 members, including lecturers at Lithuanian universities, politicians, journalists and representatives of other professions. The LPA's annual conferences (usually held in November) attract interest not only from the PS community but also from a wider audience including leading national media figures as well as European, national and local politicians. There is also the Lithuanian Public Administration Training Association, which was established in 1998 and which regularly holds thematic conferences and seminars. In addition, there are a number of civic organizations that bring together 
political scientists and representatives of the humanities and other social sciences. The presence and activity of such inter-disciplinary forums is an additional sign of their professional vitality and social relevance. For example, the Lithuanian Santara-Šviesa association (founded in the USA during the Cold War) organizes annual conferences where political scientists, along with other intellectuals and artists, give presentations and reflect on current public affairs.

The Association of Moldovan Political Scientists (AMPS) was set up in 1992 when it launched the professional journal Moldoscopie. In 2004, a rival entity, the Foreign Policy Association of the Republic of Moldovan (FPARM) was registered. However, the activities of the two professional associations, founded by lecturers at the Moldova State University, were of a certain intensity during their early lives only. Moldoscopie was renamed Revista Moldoscopie and is currently published by a private university-the Constantin Stere University of Political and Economic European Studies. FPARM is specialized in international relations. It should be said that the national community of political scientists of Moldova is divided on the question of (geo) political preferences. For example, the Association of Historians and Political Scientists "Pro Moldova", established in 2014, has supported President Igor Dodon in the 2016 presidential elections, together with the Eurasian geopolitical direction taken by the country's development. The pro-Russian association was established by a narrow group of politically engaged researchers (most of them Russian speakers), who departed from the general line of Moldova's PS community. In fact, the "Pro Moldova" illustrates the scale of corruption of political scientists by politics; that is, it reveals the substantial impact of the pressure exerted by politicians on the academic community in general and on political scientists in particular.

The Belarusian Association of Political Sciences (BAPS) was established in 1993 and formally still exists today. However, the Association performs almost no public activities. Until about 2018 another association also existed in the country, namely the "Belarusian Academy of Political Sciences"; however, this second association only really existed on paper. The situation of Belarus' PS associations demonstrates the lack of professional unity and the weakness of professional communication among political scientists, in Belarus.

The identity of PS is shaped by the job prospects and places of work of political science graduates from Lithuania, Estonia, Moldova and Belarus. According to the experts, the most common areas of employment for PS 
graduates in Lithuania and Estonia are public administration, the governing institutions of the EU and other international organizations. PS graduates are also visible in Estonia and Lithuania's national parliaments, local councils and mass media. In Moldova, most political science graduates find jobs in the mass media, different types of NGOs and the political or electoral consultancy sector.

In Belarus, the situation is not as clear, since PS departments do not gather (or do not share) data on their alumni. The graduates may find jobs in public administration as well as in business enterprises. CSOs or think tanks employ some of the graduates, while others follow academic careers, either in Belarus or abroad. However, the majority of such graduates take up careers that are not related to political science (business, art, etc.). Having a dual degree, for a considerable number of PS graduates become lawyers. It should be noted that thirty years after the fall of communism, in Belarus the practice inherited from the Soviet times, that is, the socalled first-job mandatory placement (objazatel'noe raspredelenie), still exists. Graduates are expected to work for two years at the workplace designated following their graduation.

An analysis of the four components of PS' identity (a clear separation of PS from other academic subjects, the activities of professional PS associations, visibility in the media and at public events, and finally, the favourable job prospects of PS graduates) reveals the different situations in the four post-Soviet countries examined here. In Estonia, the identity of PS derives from the existence of an island of professional excellence, highquality $\mathrm{PhD}$ programmes and research, and a limited presence in the public sphere. In Lithuania, the discipline thrives at the educational, research and public presence levels. Political scientists are often important political observers who improve the standards of political debate and who are also experts advising on the country's public affairs. Due to their prestige, PS graduates from both EU countries-Estonia and Lithuania-have relatively good career prospects in diverse professional fields.

In Moldova, the situation is much grimmer. The establishment of PS' identity is hampered by at least two factors. Firstly, the precarious economic situation and demographic crisis which has led to a deterioration in the quality of teaching and research and to a fall in student numbers (not only in the field of PS). Secondly, national politicians have interfered in the agenda of the professional PS community, with the purpose of promoting the interests of specific political figures and parties. 
Although PS programmes are formally run at diverse academic levels (including that of PhDs) and at several HE institutions, PS in Belarus is not really established as a separate academic discipline. Political scientists are not considered as representing any specific professional category. PS is confined to its own narrow community and boasts neither positive public visibility nor encouraging career prospects for graduates. Typically, PS in Belarus is placed in the "custody" of law faculties and lawyers' communities (which themselves have to abide by the dictates of the authoritarian regime and go along with the absence of the rule of law).

\section{Measuring the Autonomy of Political Science}

Chapter 2 emphasizes the fact that autonomy is an internally driven property and that the autonomy of the profession is inherently related to the autonomy of individual "professionals". To achieve autonomy the profession requires decisional independence in several areas, such as making decisions concerning enrolment, promotion and hiring, concerning relevant professional activities and their priorities, the inclusion (or exclusion) of various subfields and so on. Overall, the profession should be able to define and apply standards of institutional and personal performance. Evidently, in the governance of a complex contemporary academic sector, the rules establishing what PS, as an academic discipline, is supposed to do, achieve and perform, is substantially influenced by the broad-and changing-socio-political environment. However, PS can maintain its relative autonomy if the university itself boasts professionalism, that is, if those at the top of the academic structure are also part of the profession. In addition, the autonomy of PS is enhanced if political researchers are in a good market position and can be independent, if they do not have to run for different clients or accept patronage positions. In other words, in order to duly measure the autonomy of PS, both its institutional and individual components must be considered.

Therefore, in this section, we examine the autonomy of PS in Estonia, Lithuania, Moldova and Belarus using a series of empirical indicators. These indicators include the financial resources available measured by the share of national GDP allocated to research in general; the rules governing the allocation of funding to PS units and PS research projects; the degree of control over who is to be considered a political scientist (upon their entry to the PS community), and over their performance. The decisional autonomy of PS as a discipline manifests itself at different levels. At the 
highest level, we can measure the degree to which universities or research institutes are independent from the government in general. At the middle level, we should observe whether PS faculties and departments are independent from their respective universities' administrators (e.g. whether PS staff can shape the content of courses or research projects) and from their various social partners. Also, the presence and scope of public agencies regulating $\mathrm{HE}$ and research activities and including (or otherwise) representatives of PS communities (such as Research Councils or Academies of Science) should be taken into account.

The share of national GDP allocated to research in the four post-Soviet European states is a good proxy, as higher values of this indicator point to better conditions for research funding, which in turn contributes to the greater financial autonomy of researchers (in any academic field). In Estonia, the share of research funding as a percentage of GDP in 2018 stood at $0.8 \%$. It had fallen from $1 \%$ in previous years due to inflation and overall stagnation. In Lithuania, the value of this indicator is also $0.8 \%$. Lithuanian politicians acknowledge the problem, and regularly promise to increase the said share. In Moldova, it stood at $0.2 \%$ in 2019 and the recent trend is towards a further decrease in that figure (Cuciureanu \& Minciună, 2019). In Belarus, the share of national GDP allocated to research in 2018 was $0.61 \%$. The share had been decreasing since 2010 when it was $0.67 \%$ of GDP (Belstat, 2019).

With regard to the funding of PS research, the situation in the four countries is no less problematic. In Estonia, the situation had deteriorated when the so-called institutional research grants were replaced by individual project grants in 2015. This step led to fierce competition among scholars and to a general decrease in the amount of money allocated for research. EU support is promoted as an alternative source of funding; however, EU grants require research to offer a practical contribution to either policy-making or society as a whole, which is seen as an obstacle by scholars interested in cutting-edge academic research. The Estonian Research Council (ERC) is a special public agency dealing with the allocation of research funds.

In Lithuania, most public research funding (including EU structural loans) is allocated by the Research Council of Lithuania (RCL). The RCL makes decisions on the selection of research projects, researcher internships and the funding of academic events. Political scientists are chairs of several RCL committees, and outstanding PS researchers are frequently recruited as experts. Under a series of competitive national schemes, PS 
research has a comparatively significant likelihood of receiving funding. For example, during the 2015-2020 period the RCL has allocated around $8,300,000$ euros to 90 research team projects in the social sciences and humanities. Of these, 10 projects have been in the field of PS (either as the main or a secondary research field), and their share of the aforesaid total funding amounts to $8.3 \%$ (around 700,000 euro). ${ }^{9}$

In Moldova, the National Agency of Research and Development (NARD) is the national institutional structure in charge of competitionbased funding for research and innovation which provides funding to all research areas. Alternative forms of funding are rare, and the bulk of financial resources is allocated to budgeted institutional projects undertaken by teams of researchers. During the 2015-2019 period, around 330,000 euros were allocated, in each of those years, to 14 research projects in PS (as a main or secondary research field). The funded research projects include institutional thematic projects, bilateral research projects (conducted jointly with similar institutions in Italy, Belarus and Romania), and projects for young researchers, while grants were also awarded to fund the organization of international conferences and the publication of scientific monographs. The largest institutional thematic projects (with annual budgets ranging from 10,000 to 120,000 euro) address issues of European integration and its different aspects that are of particular pertinence to Moldova. Smaller projects (with an annual budget of 4000-9000 euro) address issues of governance, public administration and regional development (Expertonline Moldova).

In Belarus, there are two major channels for the funding of science and research: through specific institutions (institutional support), and via governmental programmes (Kazakevich \& Goroshko, 2019). The total funds available (for all areas of research) amount to about 2-4 million euros per year. Following the Soviet model, the Belarusian National Academy of Sciences (NAS) dominates the field of science and research. The NAS receives funds from the state budget and distributes them through the Belarusian Republican Foundation for Fundamental Research (BRFFR). The BRFFR allocates these resources for a two-year period in accordance with officially designated and approved national research priorities, through so-called open calls for tender (in reality, no genuine competition between projects is actually possible). In general, the activities of the

\footnotetext{
${ }^{9}$ This information was provided by the administrator of the RCL to one of the co-authors of this chapter.
} 
BRFFR are not transparent, and no information is provided regarding the amounts or recipients of grants. Noteworthy is the fact that the NAS itself is one of the main grant recipients (Kazakevich \& Goroshko, 2019). Apart from the state budget, there are almost no other sources of funding for PS research in Belarus. Alternative think tanks totally depend on international funding.

As to the rules governing the allocation of funding to academic units, Estonia has adopted a clear top-down performance-based scheme of budgeted funding from the Ministry of Education and Research to the universities, and subsequently to the individual research groups concerned. In Lithuania, the Ministry of Higher Education, Science and Sport is responsible for the funding of the country's universities; funds are distributed based on performance evaluation. Further schemes for the intra-university allocation of funds depend on the universities' internal policies. Moldova also complies with the principle of the autonomy of universities and follows similar patterns to Estonia and Lithuania in terms of resource allocation to universities. As regards the funding in Belarus, all state-run universities receive money from the national budget. HEIs further distribute receipts according to their priorities. Financially, faculties heavily depend on university administrations, which set the rules of the game (Chulitskaya, 2021).

Summing up, we may conclude that when it comes to the allocation of funding, in three of the four countries (Estonia, Lithuania and Moldova) the institutional schemes are pretty straightforward: top-down, performance-based principles of funding distribution from the ministries to the universities prevail. Belarus also has a top-down system of resource allocation; however, the principle of performance evaluation is not applied. Although Belarus has a national agency of research management (BRFFR), its tenders are mainly focused on natural and exact sciences, while the humanities and social sciences (including PS) are somewhat neglected.

The decisional autonomy of PS could also be measured by the degree of control over the members of academia when they enter the profession (i.e. who is accepted as a political scientist), the performance stage (i.e. individual or institutional level evaluations) and promotion (i.e. tenure track requirements or other upward career arrangements). We adhere to the postulate, presented in Chap. 2, that the greater the degree of external control over higher education and research institutions, the more limited their autonomy. When comparing the four post-Soviet European countries in terms of the degree of control exercised by PS institutions at the 
entry stage, what we see is that in all four countries the requirements for political scientists are set at faculty or department level. However, in Belarus, there are also governmental regulations in place. Individual performance is evaluated at both department and university levels in Lithuania and Belarus, although in the latter case this evaluation is of a rather formal nature. In Estonia, the task of individual evaluation is assigned to university departments, while in Moldova it is conducted at the university level. The institutional performance of the universities is evaluated by governmental institutions in Lithuania, Moldova and Belarus. Meanwhile, in Estonia, institutional performance assessment is conducted internally at the university level. The promotion of political scientists is supervised at department and university levels in Lithuania and Belarus. In Estonia, the rules governing the promotion of political scientists (as well as academics from other academic fields) are set at the university level. In Moldova, such rules are set by the government.

The Estonian and Lithuanian higher education sectors are dominated by result-based accountability. Higher education and research institutions are free to choose which study or research programmes to pursue, but study programmes must meet certain quality criteria (set and monitored by the national centres for quality assessment in HE). Individual and institutional research performance is measured by the number of scientific articles published in prestigious journals and by prestigious publishing houses. In Estonia, internationally acknowledged English language outlets are prioritized. In Lithuania, publications in the Lithuanian language and on "Lithuanian themes", together with publications in prestigious Western journals, are both encouraged. Accountability in teaching and research in Estonia and Lithuania is guaranteed by a mechanism of competition among national and international universities. The national universities are encouraged to achieve higher standards by operating in an environment where they must strive to attract more students (both from within the country and from abroad) and to receive more funding for research. It should be noted that such mechanisms of accountability do not significantly diminish the autonomy of universities and research institutes. However, there is another way of ensuring the accountability of studies and research; this is implemented in Belarus and, to a partial degree, in Moldova as well, and involves limiting the freedom that universities and research institutions have to decide which study or research programmes are to be pursued. In such cases, the ministries responsible for $\mathrm{HE}$ and research impose plans on universities and research institutes 
regarding which courses are to be offered, the number of specialists to be trained and the areas in which research is to be conducted. Estonia and Lithuania are characterized by better accountability assurance measures, which leads to the greater autonomy of their universities and research institutes. On the other hand, accountability assurance is more centralized in Moldova and Belarus, resulting in the limited autonomy of universities, and in particular of research institutes.

To sum up, in Estonia, the PS profession (just like other academic professions) enjoys the highest degree of decisional autonomy in regard to the recruitment and promotion of its members. In Lithuania, the political science community, like other academic communities, enjoys a rather lower degree of autonomy. However, the identity and prestige of PS in Lithuania are very strong, and this allows PS to thrive despite its somewhat limited autonomy. In Moldova, the decisional autonomy of the PS profession is significantly curtailed by economic shortages, although these are mitigated by special research funding which is of crucial importance for Moldova's statecraft. The situation in the separatist region of Transnistria (the Tiraspol University) is even more difficult, since the entire region is conflict-ridden and underfinanced, and is not only in the HE domain. In Belarus, state surveillance and control of PS in public universities are allpervasive. It is questionable whether PS can be considered an academic discipline, practiced openly, in Belarus in 2020. PS as such exists in private institutions (think tanks), but these are very dependent on external funding and unstable human resources. The case of Belarus gives rise to a rather provocative question: could political science disappear as such in the future, to go back to being something resembling the scientific communism of former Soviet times?

\section{Conclusion}

Compared to the situation in Western countries, PS as an academic discipline in the four former USSR countries (Estonia, Lithuania, Moldova and Belarus) is something of a latecomer. In these countries, it only emerged in 1990 after the fall of communism, the complete disintegration of the USSR and the changes in the system of education. Thirty years later, the four post-Soviet European states examined here boast PS as a national institutional construct and professional practice. However, PS, which in the four countries in question began life from the same impoverished basis (that of "scientific communism" and ideologically biased 
system of education) in the 1990s, took rather diverse trajectories and currently faces frequent country-specific challenges. The four countries have quite different political sciences from the point of view of the identity, autonomy and future prospects of the discipline. Democracy, pro-Western geopolitical settings and the shorter period of Sovietisation contributed to the faster, more sustainable development of the discipline in two Baltic States (Estonia and Lithuania). In Moldova, on the other hand, its uncertain geopolitical orientation and a series of serious internal political conflicts (including the unresolved conflict in Transnistria and the country's demographic and economic crises) have led to the weak identity of political science and to questionable prospects for its further institutionalization. PS finds itself in the most precarious situation in authoritarian Belarus: in that country, this academic discipline exists within a hostile political environment and under a hierarchical system of governance.

In Estonia, we observe a tendency towards the growing complexity of PS as an academic discipline. In Lithuania, PS tends to absorb and incorporate subfields of increasing diversity. In Moldova, PS as an academic discipline has undergone a process of fragmentation closely interconnected with the decrease of students and public funding. The prospects for PS in Belarus are still unclear, as it currently does not have any clear subfields, and risks further marginalization and decline. In Belarus, PS as an academic discipline crucially lacks autonomy, while the PS community is split between those who support and those who oppose, the current regime (Lukashenka). The non-democratic leader of the country de facto imposes his own outdated pro-Soviet vision of the system of ideological education which vividly interferes with PS developments. The tiny window of opportunities for the different paths of the discipline's development may open in case of liberal political changes.

In Estonia, political developments since the 2000s (neoliberalism with elements of ethno-democracy) have led to the retrenchment of PS. Demographic decline has further aggravated this situation. Changes in the tuition fee system for Estonian-language education, launched by the centre-right party Pro Patria, have resulted in the loss of opportunities to earn additional revenue from tuition fees. The country's university administrations have had to downsize their departments and study programmes. At the same time, the reform of $\mathrm{HE}$ has prompted some disciplines, including PS, to become more international and recruit more students and researchers through English-language study programmes and cuttingedge research projects. 
HE system reforms and changes have also had an impact on PS in Lithuania. One of the most important innovations in the field of HE is the thorough implementation of unified standards of research assessment and a universal system of evaluation of the quality of study programmes. The Lithuanian policy of standardizing the evaluation of educational quality has had a generally positive effect on PS, as it has raised the quality of education and furthered the internationalization of PS study programmes. Similarly, the enhanced role of the National Research Council of Lithuania (RCL), which allocates funding for research, including in the field of PS, has also had a positive impact.

In Moldova, the reforms carried out at the national level have had a rather negative impact on PS. As a result of the control exercised by the newly established National Agency for Research and Development (NARD), PS is now experiencing direct political pressure. As a result of the organized in 2018 by the NARD competition for scientific projects, since January 2020 around $40 \%$ of social science units (including PS) have received no share of budget funding. This situation resulted in a strike by the professional community at the beginning of 2020, while at the same time social scientists faced severe critics and accusation of being politically engaged agents from the prime minister. A new impetus of pro-Western developments in Moldova is expected after the election of pro-EU Maia Sandu-who has training in management and political science, obtained in Moldova and the USA - to the position of the president of the country in autumn 2020. However, experts envision that in the upcoming years, state funding of PS may be reduced even further and the prospects of PS maturation as an academic discipline might not improve significantly.

Belarus is the extreme case among the four analysed countries, in terms of the degree of political interference in HE. The Belarusian system of higher education has been constantly subjected to change; however, since the Soviet period, no full-scale reforms have ever been implemented. The conditional inclusion of Belarus in the European High Education Area (EHEA) in 2015 has not produced any improvement in this situation; the universities lack any degree of autonomy, and academic freedoms are regularly violated. PS is supposed to produce political socialization and authoritarian propaganda, just as "scientific communism" did decades ago in the USSR. However, due to the lack of any professional identity, comprehensive study programmes and career prospects for graduates, PS in Belarus has never been, and is still not, capable of playing such a role. The split of PS professional community became especially vivid during the 2020 
anti-Lukashenka protest movement when a minor part of faculties' staff (the Faculty of International Relations of BSU in particular) and many of those in think tanks publicly expressed their support of pro-democratic changes, while the majority of political scientists at public universities remain silent.

To conclude, currently despite all of the challenges and difficulties Estonia and Lithuania are faced with, they are getting closer to the Western patterns of "PS as a science of democracy", they are actively involved in international research projects and their PS communities are viable concerns. In Lithuania, political scientists experience great publicity and are active not in the professional research and expert activities but in the politics as such.

In Moldova, while PS is a clearly identified academic discipline and professional community is involved in international cooperation, political interference in academia and geopolitical uncertainties together with internal (first of all) demographic and socio-economic challenges mean that the road ahead is likely to be a difficult one. In Belarus, PS is split between state-run universities and alternative think tanks, and the PS community is heavily influenced by the country's Soviet past and by the current hostile, authoritarian political environment. International cooperation in the field of research and education in PS with the western partners is non-essential and Russia is still the most popular partner for the public universities.

\section{REFERENCES}

Antanovich, N., \& Liahovich-Petrakova, N. (2009). World Political Science and its National Dimension/ Mirovaya politicheskaya nauka i ee nacional'noe izmerenije (in Russian). Spcial'no-ekonomicheskie i pravovye issledovaniya, 4, 225.

Belstat. (2019). National Spending on Research and Development. Retrieved November 24, 2020, from http://www.belstat.gov.by/ofitsialnaya-statistika/ realny-sector-ekonomiki/nauka-i-innovatsii/graficheskiy-material-grafikidiagrammy/vnutrennie-zatraty-na-nauchnye-issledovaniya-i-razrabotki/

Chulitskaya, T. (2021). Political Science Or Science in the Service of Politics: Internal and External Co-option in Belarus (unpublished).

Cuciureanu, G., \& Minciună, V. (2019). Funding Science in the Next Period - A Way to Liquidate Organized Research in the Republic of Moldova?/Finanțarea științei în următoarea perioadă-cale de lichidare a cercetării organizate în Republica Moldova? (in Romanian). Revista de Ştiinţăa, Inovare, Cultură şi Artă “Akademos", 54(3), 27-32. 
de Waal, T., \& von Twickel, N. (2020). Beyond Frozen Conflict Scenarios for the Separatist Disputes of Eastern Europe. Retrieved November 24, 2020, from http://aei.pitt.edu/102589/1/Frozen-Conflicts-_final.pdf

Dudchik, A. Y. (2017). The Birth of Sociology from the Spirit of (Critique of Bourgeois) Philosophy?: The Belarusian Case in the 1960s Through 1980s. Stan Rzeczy, 13, 93-117.

Eisfeld, R., Eisfeld, R., \& Daryanomel. (2019). Empowering Citizens, Engaging the Public. Springer Singapore.

Galkin, A. (2010). At the Origins of Political Science Rebirth in Russia (1960-1985). Subjective Notes / U istokov vozrojdenija politicheskoi nauki v Rossii (1960-1985). Sub'ektivnye zametki (in Russian). Politiya, 3-4, 257-269.

Gorincioi, I. (2010). Science Is the Key to All Padlocks (Department of Political Science at 20 Century)/Ştiinţa e cheia tuturor lacătelor (catedra ştiinte politice la cei 20 ani) (in Romanian). Moldoscopie, 50(3), 5-10.

Greenfeld, L. (1988). Soviet Sociology and Sociology in the Soviet Union. Anmual Review of Sociology, 14, 99-123.

Gvozdeva, N. (2010). The System of Advanced Training for Party and Soviet Employees in the USSR: A Historical Review / Sistema povyshenija kvalifikacii partiinyh i sovetskih sluzjaschih v SSSR: istoricheskii ekskurs. Vestnik Povolzskogo instituta upravlenija, 3, 28-33.

Il'yn, M. (2001). National Political Science: Comprehending Traditions / Otechestvennaya politologija: Osmyslenie tradicii (in Russian). Politicheskaya nauka, $1,5-21$.

Irkhin, J. V. (2016). The Role of the Moscow Congress in IPSA Genesis: Expert Analysis/Rol' moskovskogo kongressa v genezise Mezjdunarodnoi associacii politicheskoi nauki: ekspertnyi analiz (in Russian). Political Expertise: POLITEKS, 12(1).

Jakniūnaitè, D., \& Vinogradnaité, I. (2010). Political Science in Lithuania: A Maturing Discipline. In R. Eisfield \& L. A. Pal (Eds.), Political Science in Central-East Europe: Diversity and Convergence (pp. 177-192). Barbara Budrich Publishers.

Kazakevich, A., \& Goroshko, K. (2019). Reforms of Research and Development Sector in Belarus: Challenges and Opportunities/Reforma sektora Research\&Development $\mathrm{v}$ Belarusi: vyzovy i vozmozhnosti (in Russian). Retrieved November 24, 2020, from http://palityka.org/2019/05/10368/

Kitrinos, R. W. (1984). International Department of the CPSU. Problems of Communism, 33(5), 47-75.

Levitsky, S., \& Way, L. A. (2010). Competitive Authoritarianism: Hybrid Regimes After the Cold War. Cambridge University Press.

Mazepus, H., Toshkov, D., Chulitskaya, T., \& Ramasheuskaya, I. (2017). The Effects of the EU's Scientific Cooperation Programmes on the Eastern Partnership Countries: Scientific Output and Broader Societal Impact. 
Retrieved November 24, 2020, from http://eu-strat.eu/wp-content/ uploads/2017/08/EU-STRAT-Working-Paper-No.-5.pdf

Moshneaga, V., \& Saca, V. (2004). Development of Political Science as a Science and Discipline in the Republic of Moldova. Politicheskaya Nauka, 2, 147-178.

Naumova, S. (2010). Belarusian Political Science: On the Opposite Side of the Barricade. In R. Eisfield \& L. A. Pal (Eds.), Political Science in Central-East Europe: Diversity and Convergence (pp. 61-74). Barbara Budrich Publishers.

Nemcev, M. (2016). To the History of the Soviet Academic Discipline "Introduction to the Scientific Communism" / K istorii sovetskoi akademicheskoi discipliny "Osnovy nauchnogo kommunizma" (in Russian). Retrieved November 23, 2020, from http://gefter.ru/archive/23984

Opiok, T., Sugako, L. (2010). Department of the History of CPSU at MSPI Named After A.A.Kuleshov/Kafedra istorii KPSS MGPI im. A.A.Kuleshova. Mogilev State University. Retrieved November 23, 2020, from https://libr. msu.by/bitstream/123456789/6540/1/40s.pdf

Opiok, T. V. (2019). Teaching of Social Disciplines in HEIs of BSSR (1930-1980)/ Prepodavanie obschestvennyh discipline v vuzah BSSR (in Russian). Mogilev State University. Retrieved November 23, 2020, from https://libr.msu.by/ bitstream/123456789/9512/1/569n.pdf

Pettai, V. (2010). Political Science in Estonia: Advantages of Being Small. In R. Eisfield \& L. A. Pal (Eds.), Political Science in Central-East Europe: Diversity and Convergence (pp. 119-133). Barbara Budrich Publishers.

Samoškaitė, E. (2013, January 19). D.Grybauskaitė's Colleagues at the Party School: Let the Conservatives Count how Many Former Communists are Among Them/D. D. Grybauskaitès bendradarbis partinejje mokykloje: tegul konservatoriai susiskaičiuoja, kiek tarp jụ buvusių komunistụ (in Lithuanian). Delfi. Retrieved November 24, 2020, from https://www.delfi.lt/news/daily/ lithuania/dgrybauskaites-bendradarbis-partineje-mokykloje-tegulkonservatoriai-susiskaiciuoja-kiek-tarp-ju-buvusiu-komunistu.d?id=60469325

Saprykina, D. (2016, June 18). Red Ray of Enlightenment / Krasnyi Luch Prosveschenija (in Russian). Gazeta.ru. Retrieved November 23, 2020, from https://www.gazeta.ru/science/2016/06/18_a_8312963.shtml?updated

Shevchuk, I. (2014). Plans and Curriculums of the HEIs of the Byelorussian Soviet Socialist Republic for Humanitarian Disciplines” (1920-1930s)/ Plany i programy vuzov belorusskoi sovetskoi socialisticheskoi Respubliki po gumanytarnym disciplinam (1920-1930 gg.) (in Russian). Vestnik Severnogo (Arkticheskogo federal'nogo universiteta. Seria: gumanitarnye I social'nye nauki, 3, 29-36.

Smorgunov, L. (2015). Regional political science communities in the Soviet time/ Regionel'nye politicheskie soobschestva v sovetskoe vremya (in Russian). Politicheskaya nauka, 3, 125-137. 
Theen, R. (1971). Political Science in the USSR: "To Be, Or Not To Be" Some Reflections on the Implications of a Recent Soviet Critique of American Political Science. World Politics, 23(4), 684-703. https://doi. org $/ 10.2307 / 2009856$

Vorob'ev, D. (2004). Political Science in the USSR: Formation and Development of the Scientific Community / Politologia v SSSR: formirovanie i razvitie nauchnogo soobschestva. Polis, 4, 169-178.

Open Access This chapter is licensed under the terms of the Creative Commons Attribution 4.0 International License (http://creativecommons.org/licenses/ by $/ 4.0 /$ ), which permits use, sharing, adaptation, distribution and reproduction in any medium or format, as long as you give appropriate credit to the original author(s) and the source, provide a link to the Creative Commons licence and indicate if changes were made.

The images or other third party material in this chapter are included in the chapter's Creative Commons licence, unless indicated otherwise in a credit line to the material. If material is not included in the chapter's Creative Commons licence and your intended use is not permitted by statutory regulation or exceeds the permitted use, you will need to obtain permission directly from the copyright holder.

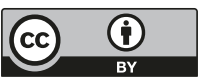

